UDC: $821.162 .4: 371.3$

Daniela M. Marčoková

OŠ „Ljudovit Štur”, Kisač

danielamarcokova@atlas.sk

Jarmila A. Hodoličová

Univerzita v Novom Sade, Filozofická fakulta

hodolic@sbb.rs

\title{
AKTIVIZUJÚCE METÓDY A STRATÉGIE VÝCHOVY A VZDELÁVANIA VO VYUČOVANÍ SLOVENSKÉHO JAZYKA A LITERATÚRY
}

Apstrakt

Pojmom inovačné trendy môžeme $\mathrm{v}$ pedagogike označit' nové tendencie smerujúce $\mathrm{k}$ dosiahnutiu pozitívnych zmien vo vyučovacom procese. Inovácie vo vyučovacom procese sa najčastejšie vzt’ahujú na nové metódy a stratégií vyučovania, ktoré sú síce efektívnejšie, no vyžadujú si viac času na prípravu a realizáciu. Tieto metódy už nie sú založené len na získanie nových poznatkov, ale ich ciel'om je naučit' žiakov s danými poznatkami pracovat', vyhl'adávat' ich a riešit' problémové úlohy. Žiaci sa učia prostredníctvom týchto metód spolupracovat' a niest' zodpovednost' za svoje vzdelávanie. Uvádzame i model intergrovaného vyčovania slovenského jazyka v 3. ročníku základnej školy s uplatnením aktivizujúcich vyučujúcich metód.

Kl'účové slová: vyučujúce metódy, intrizívna motivácia, zážitkovo - skúsenostné vyučovanie, integračná kognitívno - komunikačná koncepcia, model intergrovaného vyčovania slovenského jazyka $v 3$. ročníku základnej školy.

\section{AKTIVIZIRAJUĆE METODE I STRATEGIJE VASPITANJA I OBRAZOVANJA U NASTAVI SLOVAČKOG JEZIKA I KNJIŽEVNOSTI}

\author{
Apstrakt \\ Pojmom inovacioni trendovi možemo u pedagogiji označiti nove \\ tendencije koje su usmerene prema dostizanju pozitivnih promena u nastav-
}


nom procesu. Inovacije u nastavnom procesu se najčešće odnose na nove metode i strategije nastave koje su, doduše, efektivnije ali iziskuju mnogo više vremena za pripremu i realizaciju. Ove metode više nisu zasnovane samo na usvajanju novih znanja, već je njihov cilj naučiti učenike da rade na datim saznanjima, da ih samostalno traže i rešavaju problemske zadatke. Posredstvom ovih metoda učenici uče da sarađuju i snose odgovornost za svoje obrazovanje. Uvodimo i model integrisane nastave slovačkog jezika u 3. razredu osnovne škole sa primenom aktivizirajućih nastavnih metoda.

Ključne reči: nastavne metode, intrizivna motivacija, doživljajno-iskustvena nastava, integrativna kognitivno-komunikaciona koncepcija, model integrativne nastave slovačkog jezika u 3. razredu osnovne škole.

\section{1. ÚVOD}

Predstava toho, že by sa študent mohol tešit' z vyučovania a mat' z neho pôžitok, je často považovaná za utópiu. Existujú však vyučujúce metódy, ktoré sú protichodné ku klasickému spôsobu vyučovania a ktoré výrazne rozvíjajú kognitívne, psychomotorické, socioafektívne, interpersonálne a sebahodnotiace kompetencie žiakov. "Na podporu udržania sústredenia a záujmu počas učenia sa l'udská mysel' potrebuje rozmanitost' a kontrasty. To vyžaduje kombináciu serióznosti a odl'ahčenia, aktivity a pasivity, individuálnej a skupinovej práce, riadenej a neriadenej práce, hlučnosti a ticha počas učenia sa." (Gullach 2011: 17). Tieto metódy sú často teoreticky rozpracované len v zahraničnej literatúre, kým vo vyučovaní v našom školstve môžeme badat' iba začiatky ich uplatňovania.

\section{AKTIVIZUJÚCE METÓDY VPLÝVAJÚCE NA VNÚTORNÚ MOTIVÁCIU}

Pri výbere metód treba mat' na mysli, že existuje niekol'ko typov inteligencie: jazykový typ, logicko-matematický, priestorový, hudobný, telesne-kinetický, interpersonálny, intrapersonálny, prírodovedný, a existenciálny typ. Každý žiak (človek) vlastní všetkých devät' typov, ktoré sú u každého jedinca rozvinuté na rôznom stupni. Aktivovanie inteligencie je vo vel'kej miere ovplyvnené výberom metód učitel'a. Tiež máme na zreteli i skutočnost', že si žiaci viacej zapamätajú a interiorizujú vedomosti, ked' ich prijímajú prostredníctvom viacerých zmyslov. Podl'a Andrilovića (1979: 31), človek si takto pamätá prijaté informácie: $10 \%$ informácií, ktoré prečítal, 20 \% informácií, ktoré počul, $30 \%$ informácií, ktoré 
videl (pozoroval), $50 \%$ informácií, ktoré počul a videl, $70 \%$ toho, čo povedal (zopakoval) tak, ako je povedané, aby sa to urobilo, $90 \%$ toho, čo urobil, ako je povedané, aby sa to urobilo.

Podstatou týchto metód, na ktorých sa zakladá i súčasná výučba slovenského jazyka a literatúry je intrizívna (vnútorná) motivácia. Je to stav vyskytujúci sa vtedy, ak vykonávaná aktivita uspokojuje základné l’udské potreby po kompetentnosti a kontrole, ktoré robia aktivitu zaujímavou. Táto aktivita je vykonávaná kvôli nej samotnej a nie ako prostriedok na dosiahnutie ciel'a. Motivácia k učeniu má rôzne zdroje a môže byt' vyvolaná rôznymi spôsobmi: žiak chce byt' úspešný, lepší ako jeho spolužiak, učenie ho baví, je mu zaujímavé, chce potešit' učitel'a, rodiča, túži byt' nimi odmenení. Podl'a Kotrbu, Lacinu (2007: 81139) môžeme aktivizujúce metódy, ktoré rozvíjajú intrizívnu motiváciu členit’ na:

Problémové vyučovanie zahŕňa analýzu prípadovej štúdie, metódu čiernej skrinky, metódu konfrontácie, metódu paradoxov, úlohy na predvídanie a heuristické metódy.

Didaktické hry musia mat'vytýčený ciel' a ujasnený dôvod jej vol'by. Dôležité sú jasné pravidlá, vymedzenie úlohy vedúceho hry, časový limit hry, stanovenie spôsobu hodnotenia, zaistenie vhodného miesta a pomôcok, rekvizít alebo iného materiálu.

Diskusné metódy majú naučit' žiakov komunikovat' navzájom, vnímat' ostatných a načúvat' im. Medzi najznámejšie diskusné metódy patrí brainstorming, brainwriting, diskusia $\mathrm{v}$ spojení $\mathrm{s}$ prednáškou, ret’azová diskusia, panelová diskusia, diskusia v malých skupinkách, Gordonova metóda, Phillips 66, Hobo metóda a metóda cielených otázok.

Situačné metódy sú modelové situácie vychádzajúce z reálnych udalostí, ktoré treba vyriešit'. Ciel'om je vypracovanie alternatívnych riešení, aby sa problémová situácia $\mathrm{v}$ budúcnosti neopakovala.

Inscenačné metódy sú vhodné na zakončenie nejakej tematickej oblasti na precvičenie získaných vedomostí a intelektuálnych zručností. Často sa využívajú pri rozboroch literárnych diel. Ich podstata je $v$ stotožneni sa s pridelenými rolami.

Špeciálne metódy Do tejto kategórie patria všetky ostatné metódy, ktoré nie je možné zaradit' do predchádzajúcich kategórií, napríklad icebrekers, projektové vyučovanie alebo metóda cvičenia sa vo vnímavosti.

Podl'a iného členenia medzi aktivizujúce metódy patria: simulačné metódy (preberanie identity, icebreakers...), diskusné metódy (rozhovor, úlohy rečového typu, diskusia...), inscenačné vyučovacie metódy (hranie rolí, iniciatíva...), didaktické hry (neinteraktívne, interaktívne...), participačné metódy (prípadové metódy, brainstormingové metódy, snowballing...), projektová metóda (žiaci riešia problémy, sú nútení rozmýšl'at', skúmat', tvorit'), počítačové didaktické hry... 
Je mnoho rôznych klasifikácií moderných vyučovacích metód, ktorých spoločným menovatel'om je dôraz na kritické myslenie, učenie sa na vlastných chybách a zážitkovo - skúsenostné vyučovanie. Podstatou zážitkového učenia je objavovanie poznatkov pri vlastnej činnosti so zažitím nejakej emocionálnej skúsenosti.

"V období technického rozmachu, ked” sa dá takmer každá informácia nájst' na internete, sa prioritou vzdelávacieho procesu musí stat' rozvoj osobnosti človeka, jeho sebavedomia, schopnosti medzil'udskej komunikácie, spolupráce, tvorivého a flexibilného prístupu k riešeniu problémov či odolnosti voči stresovým a konfliktným situáciám s priamym prepojením na prax, reálny život.” (Hincová, Húsková 2011: 26).

Komunikačný model vzdelávania, tzv. rámec EUR je vhodným spôsobom ako zážitkovost' a teoretické poznatky spojit'. Prvá fáza Evokácia je zameraná na to, aby vyvolala záujem. V tejto fáze hovoria viac žiaci, úlohou učitel'a je viest' ich, povzbudzovat' $\mathrm{k}$ premýšl'aniu a pozorne počúvat'. $\mathrm{V}$ druhej fáze Uvedomenie si významu ide o skutočné učenie sa, žiaci sa oboznamujú s novými informáciami. Je dôležité udržat' ich aktivitu. V tretej fáze Reflexia si žiaci upevňujú nové vedomosti a menia na schémy porozumenia. Až tu vznikajú trvalé vedomosti. V reflexii vyjadrujú vlastnými slovami myšlienky a informácie, s ktorými sa stretli.

\section{INTEGROVANÉ VYUČOVANIE SLOVENSKÉHO JAZYKA}

Moderné vyučovanie literatúry $\mathrm{v}$ súčasnej škole uplatňuje viacero typov vyučovacích jednotiek. Za základnú vyučovaciu jednotku považujeme tzv. kombinovaný typ, v ktorej sa plní viacero didaktických funkcií: opakovanie učiva, osvojovanie si nového učiva, upevňovanie...

Základná charakteristika súčasného spôsobu chápania vyučovacieho predmetu slovenský jazyk a literatúra $v$ základnej škole je jeho integračná kognitívno - komunikačná a zážitková koncepcia. Prejavuje sa cez uplatňovanie komplexného prístupu na úrovni vnútrozložkovej a medzipredmetovej. Zakladá sa na emocionalizácii a kreativizácii diet'at'a s ciel'om formovania kultivovaného čitatel'a a recipienta iných druhov umenia. Na takýto integrovaný typ vyučovacej hodiny je potrebné vyčlenit' minimálne dve vyučovacie hodiny.

Máme na zreteli fakt, že na hodinách čítania a literárnej výchovy nie je nevyhnutné opierat' sa iba o čítankové texty a tak učitelia tento spracovaný text budú môct' využit' v plnom rozsahu. 
3.1. MODEL INTERGROVANÉHO VYČOVANIA SLOVENSKÉHO JAZYKA V 3. ROČNÍKU ZÁKLADNEJ ŠKOLY

Literárny text: Hana Zelinová: O červenom smreku

Vzdelávací ciel':

○ Literárny: čitatel'ská skúsenost' žiakov s textom, orientácia na zážitok z príjmu,

- Jazykový: upevnenie vedomostí o deminutívach, príslovkách, oslovení,

○ Slohový: tvorivé písanie, vychádzajúce z vytvorenia krátkeho listu pod'akovania žiakov smreku

Výchovný ciel': vyvodit' význam stromov pre zvieratá i človeka, ochrana životného prostredia, vyjadrenie a komunikácia citov, pod'akovanie

Komunikačný ciel': rozvíjat' zážitkové kompetencie a autentické cítenie žiakov prostredníctvom umeleckého textu, ako aj komunikačné zručnosti (aktívne počúvanie, čítanie s porozumením, tvorivé písanie, predvádzanie)

Vzdelávacie štandardy:

Základná úroveň: Určuje hlavnú udalost' a hrdinov (ktorí sú nositel'mi deja) v literárnoumeleckom texte.

Stredná úroveň: Určuje charakteristické vlastnosti, city, výhl'ad a konanie hrdinov a vzt'ahy medzi hrdinami v literárnoumeleckom texte. Všíma si vzt’ahy medzi udalost'ami (napríklad určuje poradie udalostí).

Pokročilá úroveň: Všíma si kauzálne vzt'ahy medzi udalostiami v texte. Vysvetl'uje idey v literárnoumeleckom texte, argumentuje ich odvolávajúc sa na text.

Metódy: riadený rozhovor, výtvarné stvárnenie, metódy neverbálnej komunikácie (sochy), metódy práce s textom,

Pomôcky: text rozprávky pre každého žiaka, čisté papiere, farbičky, kartičky s menami zvierat a rastlín, klbko vlny, špagát, nožnice, vystrihnuté papierové listy, vel'ký strom z papiera, vel'ký kus bieleho textilu, fixky

Korelácia: príroda a spoločnost', výtvarná výchova

Motivácia: HRA - „Lesná pavučina“ Žiaci si vylosujú kartičky s menami zvierat a rastlín. Žiaci sedia v kruhu. Jeden zo žiakov stojí v strede a má v ruke klbko vlny, ktoré rozmotáva a podáva ho prvému podl'a slova na kartičke, ktoré je vyslovené v texte. Každý hráč, ktorý počuje svoje slovo sa postaví a vezme si klbko od predošlého hráča.

Učitel' číta text: „, Ja som strom - BUK , v mojich konároch žije múdra SOVA. Celkom na vŕšku si robia hniezdo ŠKORCE. Ked' som chorý lieči ma ĎATEL'. V mojich konároch žije i VEVERIČKA, ktorá má rada LIESKOVCE. Okrem toho si pochutí niekedy aj na HUBÁCH. Huby má rád aj SLIMÁK a na 
slimáčikovi si zase pochutí JEŽKO. Podo mnou si robia hniezdo JARABICE. Mravenisko pri mojích koreňoch je plné usilovných MRAVCOV. Sem sa niekedy natára i KRTKO. DÁŽĎOVKY ZEMNÉ sa ho vel'mi boja. JELENE a ZAJACE nemám vel'mi rád, lebo mi v zime obhrýzajú kôru. “

Príde človek a vyrúbe strom. Táto pavučinka sa trhá (strihá) a život na tomto mieste - strome pre vtáčiky a zvieratká zaniká, musia si hl'adat' domov inde. Je dôležité si uvedomit', že lesy a stromy sú zložitou pavučinou života, kde všetko so všetkým súvisí o čom nás presvedčila aj táto hra.

Čo je to les? Ktoré stromy môžu v lese rást? (Učitel' ukazuje obrázky stromov: smrek, jedl'a, breza, buk, dub, borovica a lepí ich na nástenku.)

Aktivita: NAKRESLI AKO SA STROM CÍTI Predstav si, že si zrúbaný strom. Na vystrihnuté papierové listy nakresli jeden symbol, ktorý znázorňuje, ako sa strom cítil, ked’ ho šli rúbat' (napríklad - slzy, mrak, dážd'...). Dali by sa naše pocity vyjadrit' farbou? Každý žiak si vezme drevenú farbičku a vyfarbí druhú stranu lista farbou, ktorá vyjadruje jeho pocity.

Listy zalepíme na vel'ký strom vystrihnutý z papiera a zalepený na tabul'u.

Prvé čítanie textu My všetci žijeme na Zemi a robíme tu veci dobré a zlé. Všetko je však tak poprepletané, že veci, ktoré sú dobré pre nás, môžu Zemi škodit'. Meníme ju a pretvárame a myslíme si, že na to máme právo, lebo sme bystrejší a šikovnejší a všetko sa podriad’uje práve nám. Pri nasledovnom čítaní si všímajte čo je pre človeka dobré, no Zemi a iným tvorom to uškodí. / Učitel' číta text. / Zážitok z textu, čiže vzt’ah k rozprávke žiaci vyjadrujú palcom: hore - dolu - vodorovne. / Na nástenke ukážte obrázok stroma, ktorý pristal pomôct' det'om.

Aktivita: sochy Bez slov si zahráme les pred príchodom človeka. Účinkuje celá trieda. Ked' poviem CVAK, zostanete skamenení, ako na fotke. Potom si zahráme les po odchode človeka. Spravíme druhú "fotku" a potom ich v diskusii porovnávame, aké city vyjadrovali. Prvá scéna by mala byt' radostná, bezstarostná a druhá by mala vyjadrovat' smútok, spustošenie.

Aktivita: Kabát expert Učitel' v role diet'at'a sedí na stoličke pred tabul'ou. Žiaci sú v role expertov Ministerstva lesníctva a poučujú diet'a (učitel'a) ako šetrit', aby sa menej stromov pílilo. Poučujú ho i o tom, ako l'ahko môžeme našu Zem spustošit'výrubom stromov a lesov a aký to má dopad pre nás l'udí i zvieratká, ktoré tam žili.

Druhé čítanie (čítanie textu žiakmi) Podčiarknite v texte prvky živej a neživej prírody. 
Aktivita: Zhlukovanie_Učitel' do stredu tabule napíše PRÍRODA a okolo do obláčikov bude písat' slová, ktoré mu z textu budú diktovat' žiaci. (Bude nám potrebné pre realizovanie spoločnej mal'by na konci druhej hodiny.)

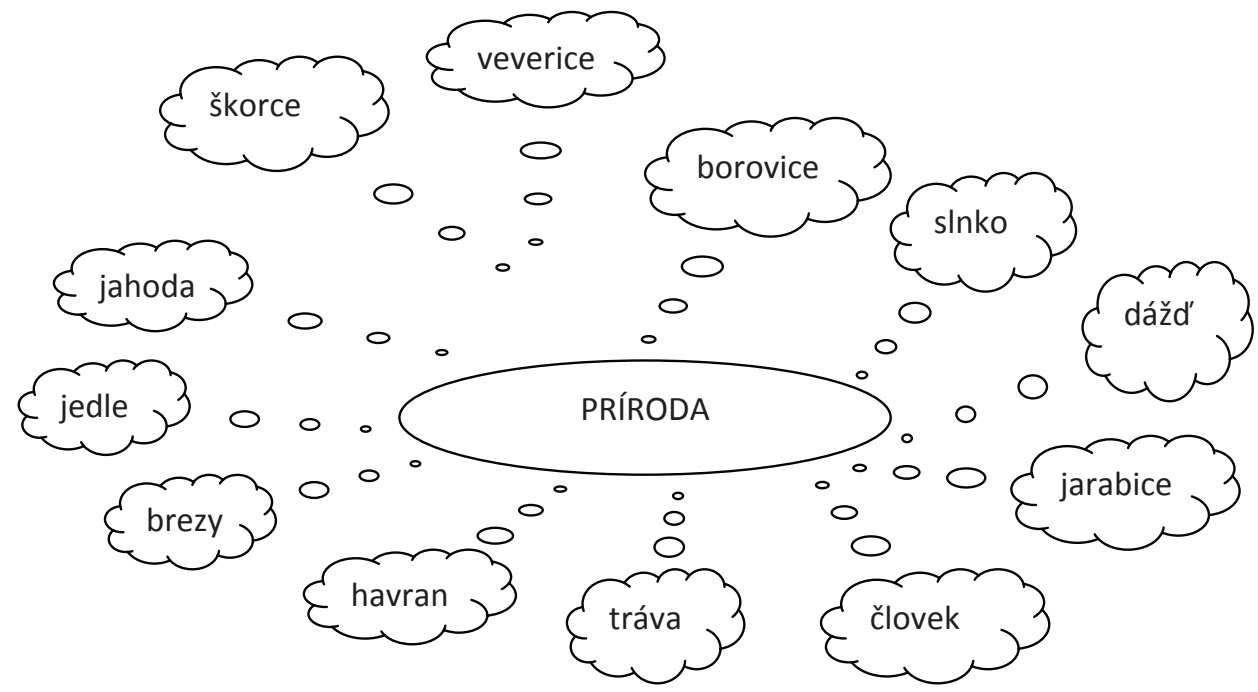

\section{DRUHÁ HODINA}

Pozrite sa do textu. Na konci niektorých odstavcov sú vety, ktoré začínajú rovnakým spôsobom. (Taký to bol smrek. Taká to bola strakatá čapica...) Žiaci ich nájdu a na základe slov, ktoré sa v tých vetách vyskytujú, žiakov podelíme na nasledovné skupiny:

1. skupina: STRAKATÁ ČAPICA Čo všetko mala čapica z prírody? Porozprávaj, čo všetko berie človek z prírody. Aké sú naśledky toho? Je to trestné?

2. skupina: SMREK Čo sa stalo so zvieratmi, ked' spílili smrek? Kam išli bývat? Predved’te nám, o čom sa asi rozprávali.

3. skupina: DETI Predved’te nám, ako by ste presvedčili smrek, aby sa dal spílit'.

4. skupina: CERUZKY Robíš v továrni. Vysvetli nám, ako vyrábate ceruzky.

5. skupina: STROMY Predved’te nám, ako sa jedle-krásavice a briezkyparádnice závodia, chvália a presviedčajú, ktorá je krajšia.

Úlohy su dané písomne. Každá skupina prezentuje vypracovanie svojej úlohy pred celou triedou. Podla potreby žiaci používajú čítanku a iné zdroje: 
encyklopédie, internet... Tak piatej skupine môžeme ponúknut' encyklopédiu o stromoch, aby vedeli argumentovat' svoju krásu.

Slohová zložka Žiaci individuálne píšu list pod'akovania smreku. Papieri potom lepia okolo stromu z aktivity Nakresli ako sa strom cíti z počiatku prvej hodiny.

Milý smrek, d’akujem Ti, že Lúto mi je, že .Tvoj-a

Výtvarná zložka - spoločná mal'ba - na vel'ký, biely kus textilu fixkami kreslíme prvky prírody. (Pomáhame si textom v obláčikoch na tabuli z aktivity Zhlukovanie.)

Aktivita: Aleja - odkazy lásky prvkom prírody Žiaci vytvoria "stromoradie pri ceste" - zastanú si do dvoch radov, čelom oproti sebe. Jeden žiak si prehodí cez seba plášt' zhotovený v predchádzajúcej aktivite. Bude predstavovat' Matku prírodu. Pomaly sa pohybuje pomedzi žiakov, ktorí ho oslovujú napríklad takto: Kvietočky, krásne voniate! Nebíčko, si vel’mi vysoko! Jahôdky, výborne chutíte! Sláviček, nádherne spievaš!... Precvičíme tak oslovenie, deminutíva a príslovky. Touto aktivitou zdôrazníme význam prírody pre človeka.

Záverečná aktivita: Hodnotenie hodiny Ako vyzerá strom ked’ sa spíli? Ako sa volajú kruhy, ktoré vidno po spílení? (Letokruhy) Do týchto letokruhov (učitel' lepí papier s letokruhmi na tabul'u) farbičkou nakreslite krúžok, srdiečko, hviezdičku... Tak vyhodnotíte dnešnú hodinu. (1 - hodina sa vám najviac páčila, 10 - hodina sa vám najmenej páčila.)

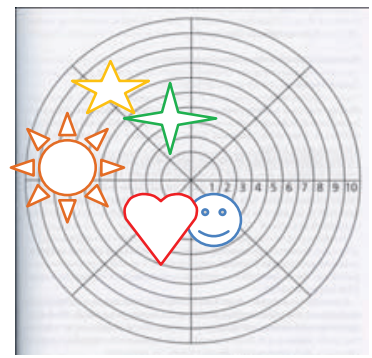


3.2. PRÍlOHA

\section{Hana Zelinová: O červenom smreku}

Hned'za mestom stál les. Za ten les slnko zapadalo, v tom lese vetrík spával a do toho lesa dúha zaháňala dážd': "Hě̌, heš, do lesa bež!"

V lese rástli jedle-krásavice, briezky-parádnice, buky, duby, krivé borovice a červený smrek.

Smrek stál na kraji lesa, preto nan̆ slnko dlhšie svietilo, vetrík ho častejšie previeval a dáždik hustejšie polieval. Hore na strome si urobili hniezda škorce a čižiky, nižšie veverice a pod smrekom jarabice. Taký to bol smrek.

O siedmej ráno prišiel do lesa človek. Na nose mal okuliare, v ruke ceruzku a nah lave strakatú čapicu. Na tú čiapku frklo slnko žltú farbu, nebo belasú, obláčik čistobielu, o tú čapicu sa obtrela jahoda spod kríčka, aj zelená trávička a zastoklo sa za ňu čierne pierko z havranieho krídla. Taka to bola strakatá čapica.

Človek dlho prezeral les. Páčili sa mu jedle-krásavice, briezky-parádnice, buky, duby, krivé borovice. Potom sa opýtal:

- Kto chce urobit' det'om radost? Kto chce darovat' drevo det'om na ceruzky? Jedle-krásavice povedali:

- My nie! My nie!

Po nich odpovedali briezky-parádnice:

- Ani my nie! Ani my nie!

- Hladaj inde! Hl'adaj inde! - volali buky, duby a krivé borovice. Také to boli stromy.

Na kraji lesa stál smrek. Odtial'to d'aleko videl a všeličo počul. Videl školu s červenou strechou, aj deti v škole a vedel, že potrebujú ceruzky.

- Ja dám det’om drevo na ceruzky! - povedal červený smrek.

- Dobre! - odvetil človek.

Potom červený smrek l’udia spílili a odviezli do mesta. V meste bola továren̆ na ceruzky. V továrni smrek rozrezali na väčšie, menšie a celkom male kolícky. Kolíčky namočili do vody, dlho ich varili, sušili, glejili a leštili. Do každého kolíčka vydlabali žliabok a naliali do neho farby zo strakatej čapice. Žltú zo slnka, modrú z oblohy, bielu z obláčka, červenú ako jahoda spod kríčka, zelenú ako trávička a čiernu ako pierko z havranieho krídla. Také to boli ceruzky.

Deti v škole vykrikli:

- Nech žijú ceruzky! - a začali písat' a kreslit’.

Danka napísala: "Hned' za mestom je les. "

Ivanko nakreslil les, za ktorý slnko zapadlo, v ktorom vetrík spával a do ktorého dúha zaháňala dáźd’: „Hěs, hě̌, do lesa bež! “ 
D. M. Marčoková, J. A. Hodoličová: AKTIVIZUJÚCE METÓDY A STRATÉGIE VÝCHOVY A ...

A vel'ký chlapec namal'oval pastelkami červený smrek, ktorý stál na kraji lesa a na ktorom si urobili hniezda škorce a čižiky, bystré veverice a plaché jarabice. Také to boli deti.

\subsection{OBRÁZKOVÁ PRÍLOHA}

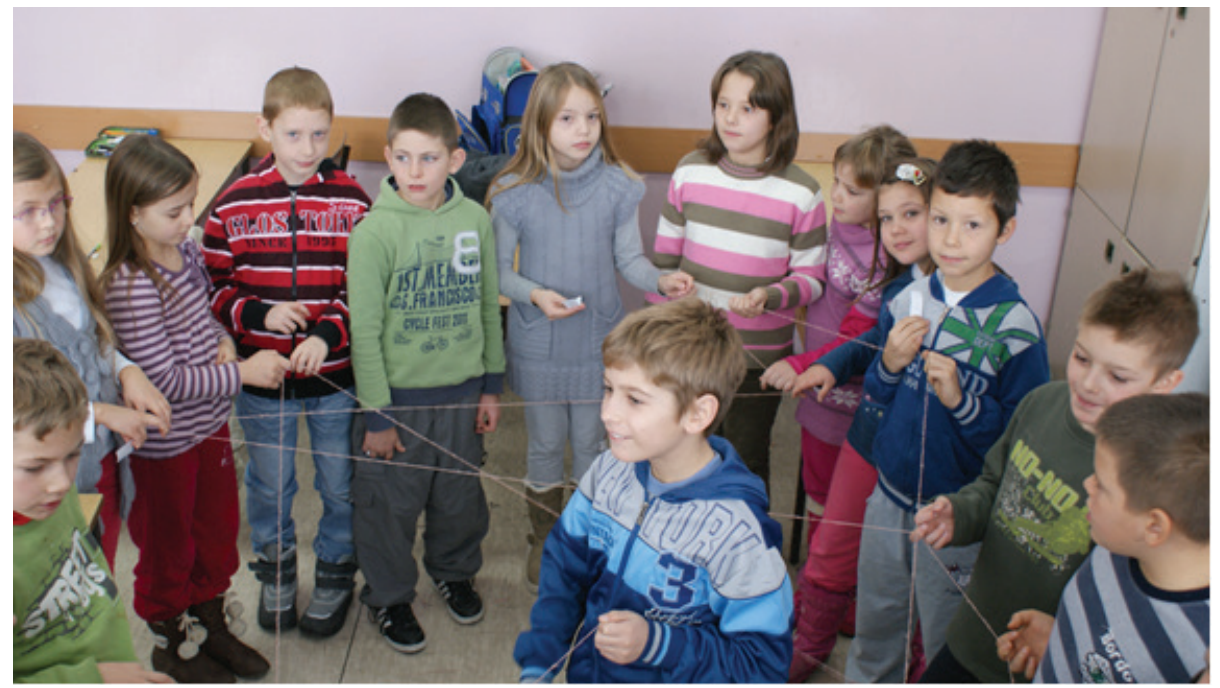

Obrázok č. 1: Aktivita „Lesná pavučina“-v prírode má všetko súvis (korelácia s prírodou a spoločnost'ou)

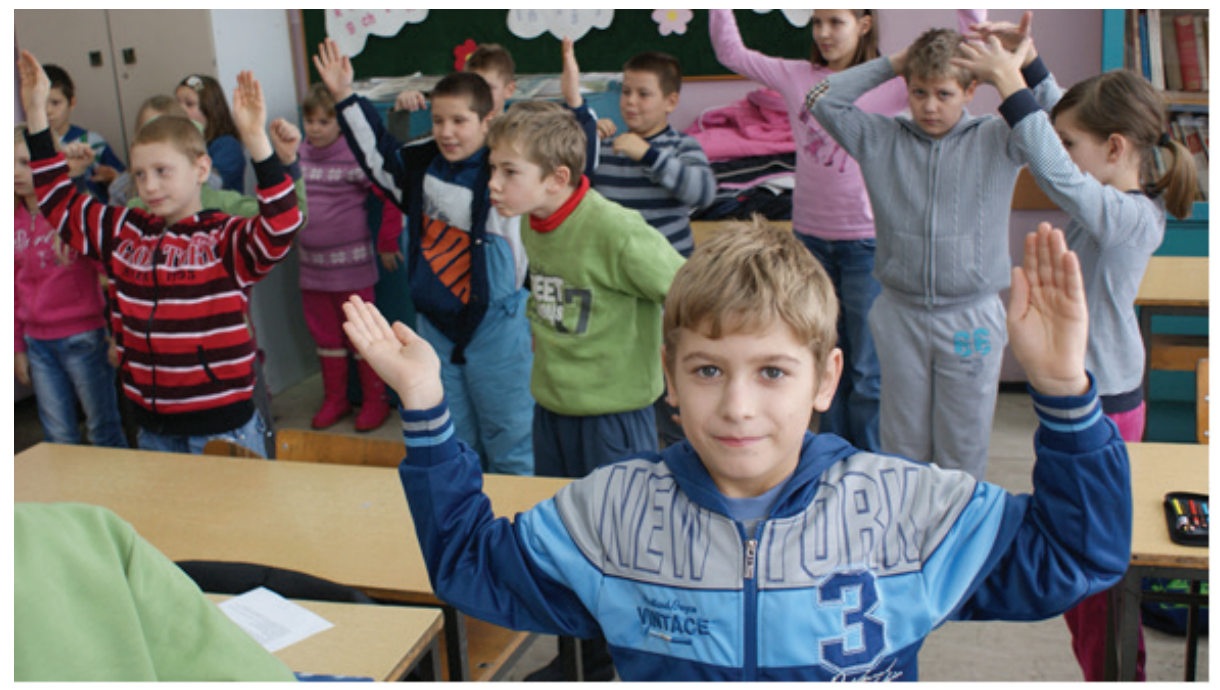

Obrázok č. 2: Aktivita „Sochy“-les pred príchodom človeka 


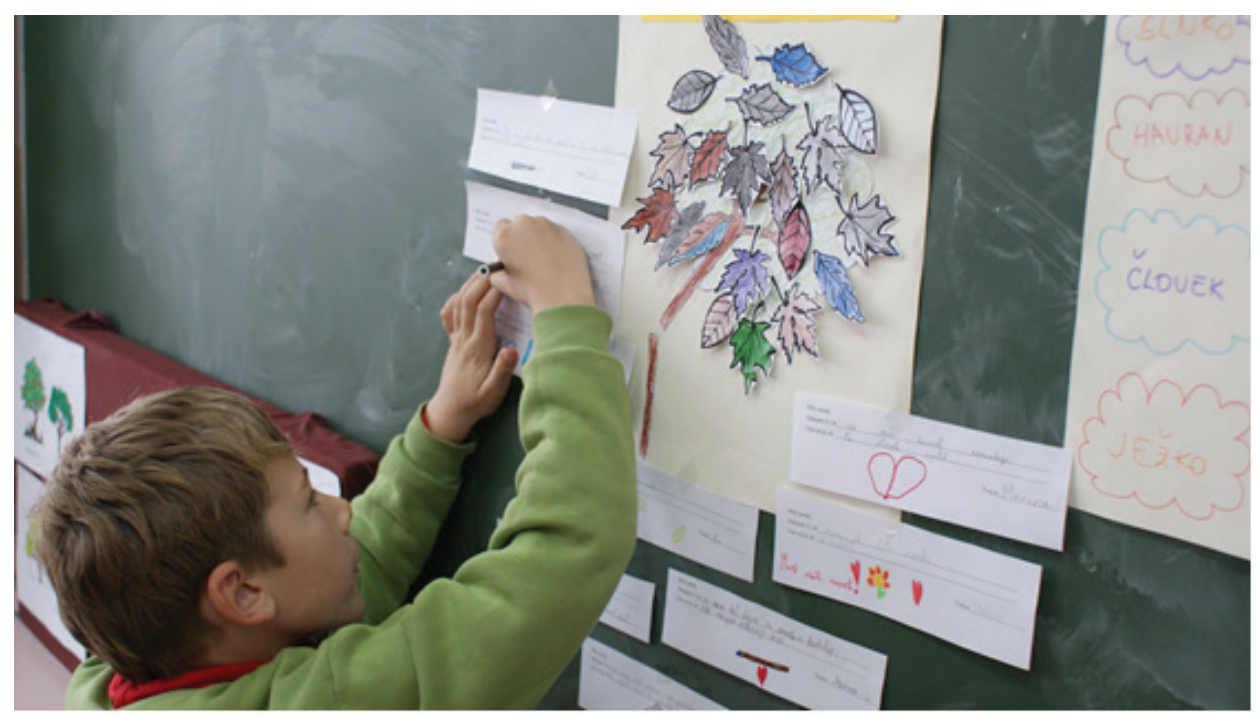

Obrázok č. 3: Písanie listu pod’akovania smreku

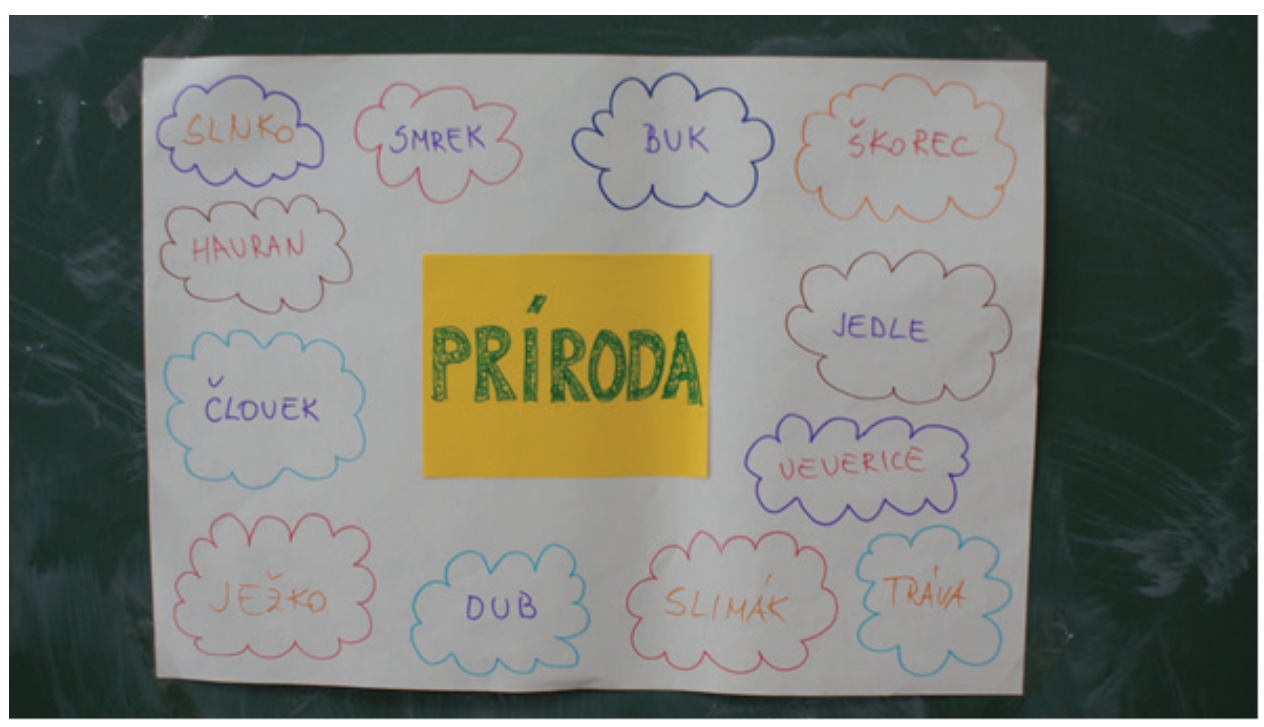

Obrázok č. 4: Prvky prírody vyskytujúce sa v spracovanom texe 


\title{
LITERATÚRA
}

Gullach, E. (2011). Zbierka metód, techník a aktivit na podporu aktívneho učenia sa. Bratislava: Metodicko-pedagogické centrum.

Hincová, K., Húsková, A. (2011). Metodika výučby slovenského jazyka a literatúry v rámci nových pedagogických dokumentov. Bratislava: Metodickopedagogické centrum.

Kotrba, T., Lacina, L. (2007). Praktické využití aktivizačních metod ve výuce. Brno: Barrister \& Principal.

\section{Daniela Marčoková \\ Jarmila Hodoličová}

\author{
STUDENTS' AND TEACHERS' ATTITUDES REGARDING LITERARY TEXTS \\ (WITH EMPHASIS ON THE TEXTS CONTAINING THE DESCRIPTIONS OF \\ NATURE) IN ELEMENTARY SCHOOLS WITH A CURRICULUM IN THE SLOVAK \\ LANGUAGE
}

\section{Summary}

Nowadays, when students seem to read books less often, textbooks are in many cases becoming the only books that bring the students in contact with literature. Taking into consideration the alienation, the busy style of life of today's people and the pursuit of material wealth as the primary goals in life, a textbook should, apart from having an aesthetic function, promote real life values; the texts should above all have an educational influence. We are interested in whether students are able to understand the educational messages of the texts by themselves, or if they need the help of a teacher. This research is directed towards analyzing the attitudes of students and their teachers regarding the texts found in textbooks, particularly those containing the descriptions of nature. The results obtained can be used for the improvement of the educational practice in elementary schools in terms of the selection of literary texts for future textbooks written in the Slovak language in Serbia.

Key words: literary texts, description of nature, educational influence, a textbook in the Slovak language in Serbia, students and teachers of elementary school. 